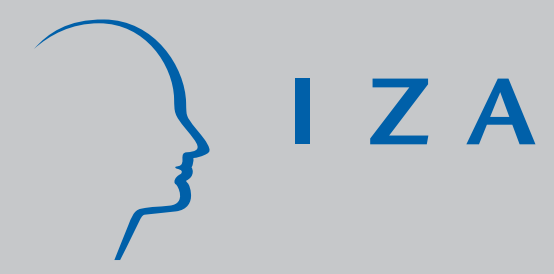

IZADP No. 2012

Performance Pay and Risk Aversion

Christian Grund

Dirk Sliwka

March 2006 


\title{
Performance Pay and Risk Aversion
}

\author{
Christian Grund \\ RWTH Aachen University \\ and IZA Bonn
}

Dirk Sliwka

University of Cologne

and IZA Bonn

Discussion Paper No. 2012

March 2006

\author{
IZA \\ P.O. Box 7240 \\ 53072 Bonn \\ Germany \\ Phone: +49-228-3894-0 \\ Fax: +49-228-3894-180 \\ Email: iza@iza.org
}

Any opinions expressed here are those of the author(s) and not those of the institute. Research disseminated by IZA may include views on policy, but the institute itself takes no institutional policy positions.

The Institute for the Study of Labor (IZA) in Bonn is a local and virtual international research center and a place of communication between science, politics and business. IZA is an independent nonprofit company supported by Deutsche Post World Net. The center is associated with the University of Bonn and offers a stimulating research environment through its research networks, research support, and visitors and doctoral programs. IZA engages in (i) original and internationally competitive research in all fields of labor economics, (ii) development of policy concepts, and (iii) dissemination of research results and concepts to the interested public.

IZA Discussion Papers often represent preliminary work and are circulated to encourage discussion. Citation of such a paper should account for its provisional character. A revised version may be available directly from the author. 
IZA Discussion Paper No. 2012

March 2006

\section{ABSTRACT}

\section{Performance Pay and Risk Aversion}

A main prediction of agency theory is the well known risk-incentive trade-off. Incentive contracts should be found in environments with little uncertainty and for agents with low degrees of risk aversion. There is an ongoing debate in the literature about the first trade-off. Due to lack of data, there has so far been hardly any empirical evidence about the second. Making use of a unique representative data set, we find clear evidence that risk aversion has a highly significant and substantial negative impact on the probability that an employee's pay is performance contingent.

JEL Classification: J33, M52, D80

Keywords: risk, incentives, agency theory, risk aversion, performance appraisal, pay for performance, GSOEP

Corresponding author:

Dirk Sliwka

University of Cologne

Herbert-Lewin-Str. 2

50931 Köln

Germany

Email: dirk.sliwka@uni-koeln.de 


\section{Introduction}

There is an ongoing debate on the empirical test of predictions made by agency models. A key area of investigation has been the importance of risk considerations for incentive contracting. Prendergast (1999) for instance surveys the empirical literature and concludes that "while agents do appear to respond to incentives, it would not appear that on the margin, the risk measures that have been considered are the true constraining factors on the provision of incentives".

The focus of the empirical investigations has been the predicted negative trade-off between measures of uncertainty and pay-for-performance sensitivity (Allen and Lueck (1992), Lafontaine (1992), Aggarwal and Samwick (1999), Ackerberg and Botticini (2002), Hilt (2006), Wulf (forthcoming)). As discussed for instance by Prendergast (2002) the evidence on this is weak or even seems to contradict predictions from standard moral hazard models.

But an important variable governing the trade-off between risk and incentives that has not been directly addressed with field data is the agent's risk aversion. ${ }^{1}$ This is due to the fact that it seeems hardly measurable in many contexts. Allen and Lueck (1995) for instance state that "since individual risk preferences are not measurable, the predictions [from risk sharing models] using preference parameters are never testable" or Chiappori and Salanié (2003) stress that "although risk aversion plays a crucial role in the story, it is not directly observable".

We use a unique dataset to investigate the connection between indivdiual risk aversion and the incidence of performance pay. The 21st-wave of the German Socioeconomic Panel, a representative survey of the people living in Germany, offers this unique possibility for two reasons. First of all, this wave of the panel for the first time contains information on whether an employee's performance is evaluated and wages are performance contingent. In addition, this wave contains a novel set of questions measuring an individual's risk attitudes. Dohmen et al. (2005) have validated this measure experimentally by showing that the measure is a good predictor of actual

\footnotetext{
${ }^{1} \mathrm{Up}$ to now there have been some attempts to control for risk aversion indirectly in empirical studies by using proxies like wealth and assuming that risk aversion is decreasing in wealth (see e.g. Laffont and Matoussi (1995)). Recently, Dohmen and Falk (2006) found experimental evidence that risk averse agents self select into fixed pay contracts rather than into tournaments.
} 
risk-taking behavior in lottery choice experiments.

In our dataset we cannot observe the direct pay-for-performance sensitivity in the employment contracts. But we observe a dichotomous variable indicating whether or not an employee receives performance contingent wage payments. A key problem an employer faces when deciding on whether to use performance contingent wages is that performance measurement will typically be costly and he therefore has to trade-off the costs of performance appraisal against the benefits. Therefore we first built a very simple model in which a principal can decide on whether to install a costly performance appraisal system as a precondition to introduce performance pay. As the benefits of performance pay decrease when the agent is more risk averse, we show that the probability of offering a fixed wage should increase when the agent is more risk averse.

Our empirical study strongly confirms this prediction based on standard agency theoretical considerations. We find a not only highly significant but also economically substantial negative effect of an employee's risk aversion on the probability that his wage is peformance contingent. Hence, individual risk attitudes indeed do seem to be an important constraining factor on the provision of incentives.

\section{A Simple Model}

We consider a very simple Holmström/Milgrom-type model. A risk neutral principal employs an agent. The agent is risk averse with a coefficient of absolute risk aversion $r$. He chooses an effort level $e$ at costs $C(e)$ where $C^{\prime \prime}(e)>0$. Following Holmström and Milgrom (1991) we assume that the agent enjoys exerting effort up to a certain level $\bar{e}>0$ such that $C^{\prime}(\bar{e})=0$. The principal can measure the agent's output when he installs a system for performance appraisal at costs $k$. When she has done so, the agent's output $s=e+\varepsilon$ becomes verifiable, where $\varepsilon$ is some normally distributed random noise component with variance $\sigma_{\varepsilon}^{2}$. The agent's reservation wage is $w_{a}$. When the principal installs the appraisal system the compensation contract of the agent is given by $\alpha+\beta s$. Without an appraisal system she can only pay a fixed wage.

When no appraisal system is installed the agent exerts his intrinsically preffered effort level $\bar{e}$. As the participation constraint is binding the prin- 
cipal pays a wage $w_{a}+C(\bar{e})$ and earns expected profits

$$
\bar{e}-w_{a}-C(\bar{e}) .
$$

When an appraisal system is installed the agent's certainty equivalent is $\alpha+\beta e-C(e)-\frac{1}{2} r \sigma_{\varepsilon}^{2} \beta^{2}$. Taking the agent's binding participation constraint and the incentive constraint $\beta=C^{\prime}(e)$ into account, the principal maximizes her profits

$$
\max _{e} e-w_{a}-C(e)-\frac{1}{2} r \sigma_{\varepsilon}^{2}\left(C^{\prime}(e)\right)^{2}-k .
$$

Taking the first derivative with respect to $e$ and replacing $C^{\prime}(e)$ with $\beta$, we obtain the standard characterization of the optimal pay-for-performance sensitivity

$$
\beta^{*}=\frac{1}{1+r \sigma^{2} C^{\prime \prime}\left(e^{*}\right)}>0 .
$$

Hence, the agent's optimal effort level $e^{*}$ characterized by $\beta^{*}=C^{\prime}\left(e^{*}\right)$ exceeds his intrinsically favoured level $\bar{e}$.

The principal will therefore implement an appraisal system whenever

$$
e^{*}-w_{a}-C\left(e^{*}\right)-\frac{1}{2} r \sigma_{\varepsilon}^{2}\left(C^{\prime}\left(e^{*}\right)\right)^{2}-k \geq \bar{e}-w_{a}-C(\bar{e}) .
$$

For $k=0$ the condition always holds. When $k$ is very large it can never hold. Note that $\bar{k} \equiv e^{*}-C\left(e^{*}\right)-\bar{e}+C(\bar{e})$ constitutes an upper boundary on the principal's returns from using performance pay. For $k>\bar{k}$ the principal will stick to fixed wages irrespective of the agent's risk aversion. When $0<k<\bar{k}$, the principal's decision on whether to appraise the agent's performace depends on $r$. For $r=0$ the principal will always measure the agent's performance and for $r \rightarrow \infty$ she will never do so. Applying the envelope theorem it can directly be derived that the left hand side is strictly decreasing in $r$. Hence, we can conclude:

Proposition 1 When $k \geq \bar{k}$ the principal always offers a pure fixed wage. When $0<k<\bar{k}$ there is a cut-off value for the agent's coefficient of absolute risk aversion $r$ such that his performance is measured and his pay is performance contingent if and only if $r$ is smaller than this cut-off.

In this simple agency model a firm negotiates a compensation package with a given agent and those negotiations lead to fixed wages when the 
agent is very risk averse and to performance pay when this is not the case and performance measurement is not too costly. But of course there is also a matching and selection issue. Note that the firm's profits are strictly decreasing in the agent's risk aversion when performance is measured. However, when it is not measured, profits do not depend on the agent's risk attitudes at all. Hence, when a position has to be filled where performance can be measured rather easiliy such that $k<\bar{k}$ the firm will hire agents with a low degree of risk aversion. But for positions where performance measurement is very costly such that $k \geq \bar{k}$, the firm does not care at all about $r{ }^{2}$ Hence, we should still observe that the probability that an employee receives performance contingent wages is decreasing in the degree of his risk aversion.

Here the matching issue reaffirms the predictions obtained from the analysis of contracting in a fixed principal-agent relationship. In contrast, when the connection between uncertainty and incentives is considered, matching may lead to a reversal of predictions as for instance discussed by Ackerberg and Botticini (2002), Li and Ueda (2005) or Serfes (2005).

\section{Empirical Evidence}

\subsection{The Data}

We make use of the German socio-economic panel (GSOEP), a large representative survey of people living in Germany, which has been extensively used for exploring various research questions before. ${ }^{3}$ The questionnaire has been extended in the latest available (21st) wave (2004) with respect to two very interesting aspects: First, people are asked whether their job performance is regularly assessed by a superior as part of an agreed procedure and if yes, whether this performance evaluation influences their monthly gross wage, yearly bonus, future salary increases and/or potential promotions. ${ }^{4}$

\footnotetext{
${ }^{2}$ Jullien et al. (forthcoming) analyse optimal screening when the principal does not know the agent's risk-aversion and show that the power of incentives decreases with riskaversion.

${ }^{3}$ See http://www.diw.de/english/sop/index.html for a detailed description of the data set.

${ }^{4}$ We thank the GSOEP-Team from the German Institute of Economic Research (DIW, Berlin), who followed our suggestion to incorporate these questions in the 2004 questionnaire.
} 
Second, this wave of the GSOEP contains a novel set of questions measuring individual risk attitudes on an 11-point scale from 0 "unwilling to take risks" to 10 "fully prepared to take risks". Next to a general risk attitude question, there is also information for different areas of life like e.g. the risk attitude in the occupational career. Dohmen et al. (2005) have validated this measure experimentally by showing that it is a good predictor for actual risk taking behaviour in lottery choice experiments. For the first time, it is therefore possible to analyze the link between individual risk aversion and performance based pay with field data.

The GSOEP contains information on performance evaluation and its impact on monthly wages, bonuses, future wage increases and possible promotions of about 7,500 full and part-time working employees, which are not older than 65 years (the regular retirement age). Performance is evaluated regularly by a superior as part of an agreed procedure for 31 per cent of these employees. One quarter of the employees, whose performance is appraised systematically, affirm an impact on the monthly wage, one third on bonuses, 40 percent on future wage increases and a half on possible promotions. Multiple answers were feasible. Two thirds of the individuals with performance appraisals affirm that the evaluation has at least one of these consequences.

\section{$3.2 \quad$ Results}

On the 11-point scale, the average willingness to take risks in the area of the occupational career differs significantly between individuals with (4.25, $s d=2.44)$ and without $(3.75, s d=2.48)$ performance appraisals (T-test, $p<0.001)$. This significant difference of the willingness to take risks between individuals without and with performance appraisals holds for the whole distribution (see Figure 1, Kolmogorov-Smirnov test, $p<0.001$ ). The difference is even larger compared to the subgroup of individuals with performance appraisals, who report a monetary impact on their bonus (mean = $4.48, s d=2.47)$. This and all further results do qualitatively hold also for the general risk attitude variable. The bivariate correlation between both risk attitude variables is high (0.59), but not perfect. The risk attitude of individuals can therefore differ across areas of life.

We estimate a binary probit approach to investigate the effect of an individual's risk attitutes on the probability that his or her performance 


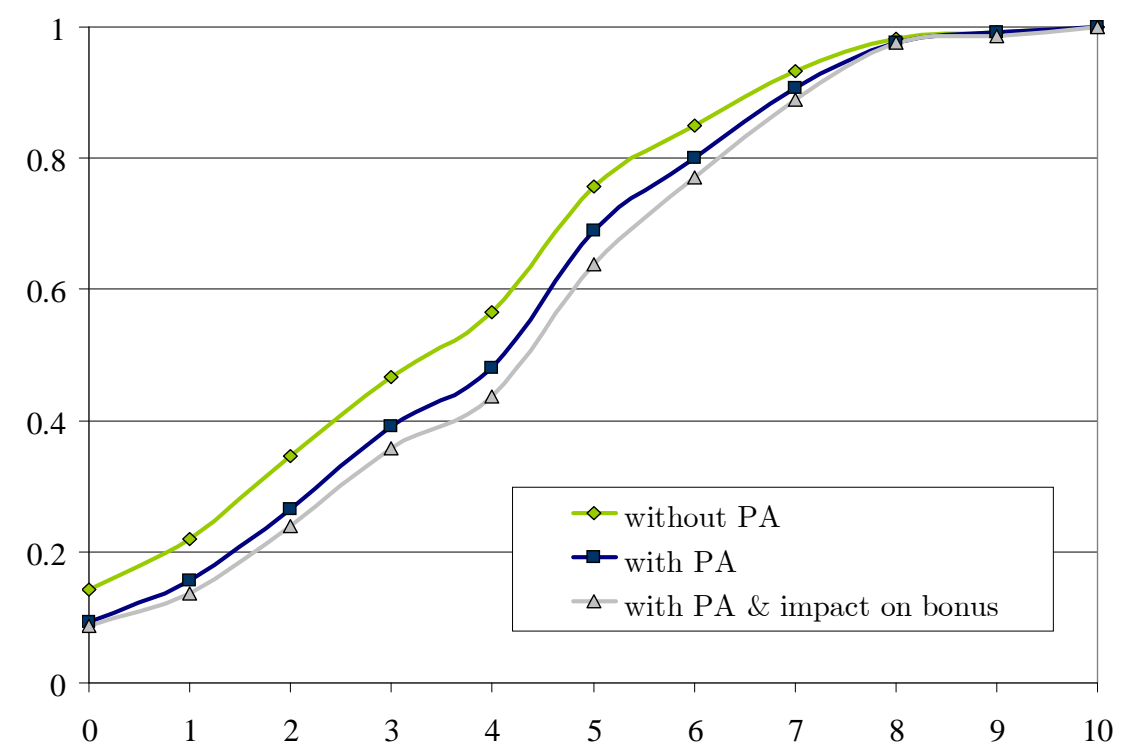

Figure 1: Cumulative distribution of the willingness to take risks

is appraised and that this appraisal has monetary consequences. As other individual (sex, age, and years of schooling) and job based characteristics (tenure, working hours, job status, firm size, industry and region) may influence the probability of performance appraisals we control for them in our analysis. We generated twelve industry dummies. Firm size categories are also measured with a set of 6 dummy variables indicating the number of employees. Job status covers 15 categories of blue collar and white collar workers as well as civil servants with different job requirements and responsibility levels. Tenure is stated in years.

Indeed, model (1) confirms a highly significant positive relationship between the willingness to take risks and the fact that an employee's performance is appraised which is well in line with predictions based on agency models. But as indicated above, the fact that the performance of an employee is appraised not necessarily implies that this appraisal has monetary consequences. Hence, we estimated the impact of risk attitudes on the probability that an employee's performance is appraised and this appraisal has monetary consequences (i.e. on either monthly wages, bonus, future wage increases or promotions) in model (2) which leads to the same observation. The same is true if we only consider appraisals which affect bonus payments 


\begin{tabular}{|c|c|c|c|c|}
\hline & $\begin{array}{c}\text { (1) } \\
\text { Performance } \\
\text { appraisal }\end{array}$ & $\begin{array}{c}(2) \\
\text { Appraisal \& } \\
\text { monetary } \\
\text { consequences }\end{array}$ & $\begin{array}{l}(3) \\
\text { Appraisal \& } \\
\text { impact on } \\
\text { bonus }\end{array}$ & $\begin{array}{c}(4) \\
\text { Appraisal \& } \\
\text { no monetary } \\
\text { consequences }^{a}\end{array}$ \\
\hline $\begin{array}{l}\text { Risk attitude }^{b} \\
\text { (career risks) }^{\text {cark }}\end{array}$ & $\begin{array}{c}0.031^{* * *} \\
(0.007)\end{array}$ & $\begin{array}{c}0.031^{* * *} \\
(0.008)\end{array}$ & $\begin{array}{c}0.032^{* * *} \\
(0.009)\end{array}$ & $\begin{array}{c}0.013 \\
(0.011)\end{array}$ \\
\hline Female & $\begin{array}{c}-0.136^{* * *} \\
(0.041)\end{array}$ & $\begin{array}{c}-0.232^{* * *} \\
(0.048)\end{array}$ & $\begin{array}{c}-0.257^{* * *} \\
(0.053)\end{array}$ & $\begin{array}{l}0.066 \\
(0.065)\end{array}$ \\
\hline Age & $\begin{array}{c}-0.004^{*} \\
(0.002)\end{array}$ & $\begin{array}{c}-0.010^{* * *} \\
(0.002)\end{array}$ & $\begin{array}{l}-0.002 \\
(0.003)\end{array}$ & $\begin{array}{l}0.004 \\
(0.003)\end{array}$ \\
\hline Years of schooling & $\begin{array}{l}-0.003 \\
(0.008)\end{array}$ & $\begin{array}{l}-0.007 \\
(0.010)\end{array}$ & $\begin{array}{c}0.014 \\
(0.010)\end{array}$ & $\begin{array}{l}0.007 \\
(0.014)\end{array}$ \\
\hline Tenure & $\begin{array}{l}-0.002 \\
(0.002)\end{array}$ & $\begin{array}{l}-0.000 \\
(0.003)\end{array}$ & $\begin{array}{c}0.001 \\
(0.003)\end{array}$ & $\begin{array}{l}0.004 \\
(0.003)\end{array}$ \\
\hline Part time & $\begin{array}{c}-0.115^{* *} \\
(0.048)\end{array}$ & $\begin{array}{c}-0.201^{* * *} \\
(0.061)\end{array}$ & $\begin{array}{c}-0.289^{* * *} \\
(0.072)\end{array}$ & $\begin{array}{l}-0.032 \\
(0.070)\end{array}$ \\
\hline East German & $\begin{array}{c}0.026 \\
(0.040)\end{array}$ & $\begin{array}{c}-0.123^{* *} \\
(0.050)\end{array}$ & $\begin{array}{c}-0.101^{*} \\
(0.054)\end{array}$ & $\begin{array}{c}0.200^{* * *} \\
(0.060)\end{array}$ \\
\hline \multicolumn{5}{|c|}{ Firm Size (Reference $<5$ employees): } \\
\hline $5-19$ & $\begin{array}{c}0.307^{* * *} \\
(0.099)\end{array}$ & $\begin{array}{c}0.351^{* *} \\
(0.149)\end{array}$ & $\begin{array}{c}0.353^{* *} \\
(0.172)\end{array}$ & $\begin{array}{c}0.069 \\
(0.135)\end{array}$ \\
\hline $20-99$ & $\begin{array}{c}0.536^{* * *} \\
(0.096)\end{array}$ & $\begin{array}{c}0.579^{* * *} \\
(0.145)\end{array}$ & $\begin{array}{c}0.587^{* * *} \\
(0.167)\end{array}$ & $\begin{array}{c}0.401^{* * *} \\
(0.126)\end{array}$ \\
\hline 100-199 & $\begin{array}{c}0.725^{* * *} \\
(0.102)\end{array}$ & $\begin{array}{c}0.734^{* * *} \\
(0.150)\end{array}$ & $\begin{array}{c}0.724^{* * *} \\
(0.173)\end{array}$ & $\begin{array}{c}0.410^{* * *} \\
(0.140)\end{array}$ \\
\hline 200-1999 & $\begin{array}{c}0.970 * * * \\
(0.094)\end{array}$ & $\begin{array}{c}1.014^{* * *} \\
(0.143)\end{array}$ & $\begin{array}{c}0.941^{* * *} \\
(0.164)\end{array}$ & $\begin{array}{c}0.599^{* * *} \\
(0.125)\end{array}$ \\
\hline$\geq 2000$ & $\begin{array}{c}1.267^{* * *} \\
(0.094)\end{array}$ & $\begin{array}{c}1.326^{* * *} \\
(0.142)\end{array}$ & $\begin{array}{c}1.142^{* * *} \\
(0.164)\end{array}$ & $\begin{array}{c}0.781^{* * *} \\
(0.126)\end{array}$ \\
\hline Industry dummies & yes & yes & yes & yes \\
\hline Job status dummies & yes & yes & yes & yes \\
\hline Observations & 7598 & 7073 & 7413 & 5680 \\
\hline Pseudo $\mathrm{R}^{2}$ & 0.13 & 0.20 & 0.14 & 0.06 \\
\hline Log likelihood & -4080.71 & -2806.91 & -2212.00 & -1462.89 \\
\hline
\end{tabular}

Binary Probit Estimations, robust standard errors in parentheses.

* significant at $10 \%$; ** significant at $5 \%$; *** significant at $1 \%$.

${ }^{a}$ Individuals whose appraisals have monetary consequences are omitted in model (4).

$b$ 11-point scale from 0 "unwilling to take risks" to 10 "fully prepared to take risks". 
in model $(3) .^{5}$

However, it may still be possible that risk averse people dislike being monitored in general and therefore it is less likely that their performance is evaluated even when such an appraisal has no direct monetary consequences. To test this, we construct a dummy variable which is equal to 1 when an individual's performance is appraised but this appraisal has no monetary consequences. Comparing this group of employees with individuals without any form of performance appraisal (model 4), no significant effect of the risk attitude can be observed. Hence, performance evaluation has to have economic consequences in order to be associated to individual risk attitudes. These results do also hold for subgroups of employees with respect to gender, working hours and job status.

But it is of course important to estimate not only the statistical but also the economic significance of the observed effect. To do this, we use the probit results to compare the estimated probabilities for performance appraisals at different quantiles of the distribution of risk attitudes. We find that a person at the $75 t h$ percentile of the willingness to take risks has a 16 per cent higher chance that his performance is appraised than his counterpart at the $25 t h$ percentile. Looking at the impact on the probability of receiving bonus payments, this relative inter-quartile range is even 27 per cent. ${ }^{6}$ Hence, the effect is also substantial in economic terms. Our results therefore strongly support the risk-incentive trade-off suggested by agency models.

The results with respect to the control variables indicate that men rather than women and full-time rather than part-time workers have jobs with performance appraisals. Furthermore, we find that performance is evaluated more often in larger firms. But years of schooling and tenure do not matter. The performance of older employees is slightly less often evaluated. This age effect becomes much stronger when we do not control for risk attitutes which is due to a positive effect of age on risk aversion.

\footnotetext{
${ }^{5}$ The reference group in model (2) are all individuals without appraisals or whose appraisals have no monetary consequences and in model (3) all individuals without appraisals and those where appraisals have no impact on bonus payments. Analogous estimations using the impact on monthly wages, future wage increases and promotions confirm this result. The sample size is decreasing in these specifications, because not every individual has responded to these questions.

${ }^{6}$ These results are computed at the mean of all other independent variables in model (1) and (3) respectively.
} 


\section{Conclusion}

Making use of a new and unique data set, we analyze the link between performance pay and employees' risk attitudes. Therefore, it is possible for the first time to explore the risk aversion-incentive trade-off suggested by agency theory with field data. We find clear evidence that the indidvidual risk aversion of an employee has a significantly negative and substantial impact on the probability that his performance is evaluated and that he receives performance contingent wages.

An important task for further research is to explore the triangular interrelation between individuals' risk aversion, uncertainty of the environment, and incentive contracts simultaneously. The difficulty is of course to obtain measures of individual employee's risk preferences at the same time as measures of uncertainty in the performance signals used by their employers. But the growing availability of matched employer-employee datasets gives some hope that this may become possible in the near future.

\section{References}

Ackerberg, D. and Botticini, M. (2002): Endogenous Matching and the Empirical Determinants of Contract Form. Journal of Political Economy, 110, pp. 564-591.

Aggarwal, S. and Samwick, A. (1999): The Other Side of the Tradeoff: The Impact of Risk on Executive Compensation. Journal of Political Economy, 107, pp. 65-105.

Allen, D.W. and Lueck, D. (1992): Contract Choice In Modern Agriculture: Cash Rent vs. Cropshare. Journal of Law and Economics, 35, pp. 397-426.

Allen, D.W. and Lueck, D. (1995): Risk preferences and the economics of contracts. American Economic Review (Papers and Proceedings), 85, pp. $447-51$.

Chiappori, P. A. and Salanié, B. (2003): Testing Contract Theory: A Survey of Some Recent Work. In: Dewatripont, Hansen L.P. Turnovski S., M. (Ed.) Advances in Economic Theory, Eigth World Congress of the Econometric Society, Vol. 1, Cambridge University Press, Cambridge, pp. 115-149.

Dohmen, T. and Falk, A. (2006): Performance Pay and Multi-dimensional Sorting: Productivity, Preferences and Gender. IZA Discussion Paper No. 2001. 
Dohmen, T., Falk, A., Huffman, D., Sunde, U., Schupp, J. and Wagner, G.G. (2005): Individual Risk Attitudes: New Evidence from a Large, Representative, Experimentally-Validated Survey. IZA DP Discussion Paper No. 1730 .

Hilt, E. (2006): The Negative Trade-off Between Risk and Incentives: Evidence from the American Whaling Industry. NBER Working Paper No. 11960 .

Holmström, B. and Milgrom, P. (1991): Multitask Principal-Agent Analyses: Incentive Contracts, Asset Ownership and Job Design. Journal of Law, Economics and Organization, 7, pp. 24-52.

Jullien, B., Salanié, B. and Salanié, F. (forthcoming): Screening Risk-Averse Agents under Moral Hazard. Economic Theory.

Laffont, J. J. and Matoussi, M. S. (1995): Moral Hazard, Financial Constraints and Sharecropping in El Oulja. The Review of Economic Studies, 62, pp. 381-399.

Lafontaine, F. (1992): Agency Theory and Franchising: Some Empirical Results. Rand Journal of Economics, 23, pp. 263-283.

Li, F. and Ueda, M. (2005): CEO-Firm Match and Principal-Agent Theory. CEPR Discussion Paper 5119.

Prendergast, C. J. (1999): The Provision of Incentives in Firms. Journal of Economic Literature, 37, pp. 7-63.

Prendergast, C. J. (2002): The Tenuous Tradeoff between Risk and Incentives. Journal of Political Economy, 110, pp. 1071-1102.

Serfes, K. (2005): Risk Sharing vs. Incentives: Contract Design under Twosided Heterogeneity. Economics Letters, 88, pp. 343-249.

Wulf, J. (forthcoming): Authority, Risk, and Performance Incentives: Evidence from Division Manager Positions Inside Firms. Journal of Industrial Economics. 